\title{
Recorregut de recerca geològica i geoambiental per les comarques de l'Anoia i del Bages: des de la Serra de Rubió a Castellfollit del Boix i a Rajadell
}

Josep Maria Mata-Perelló

Joaquim Sanz Balagué

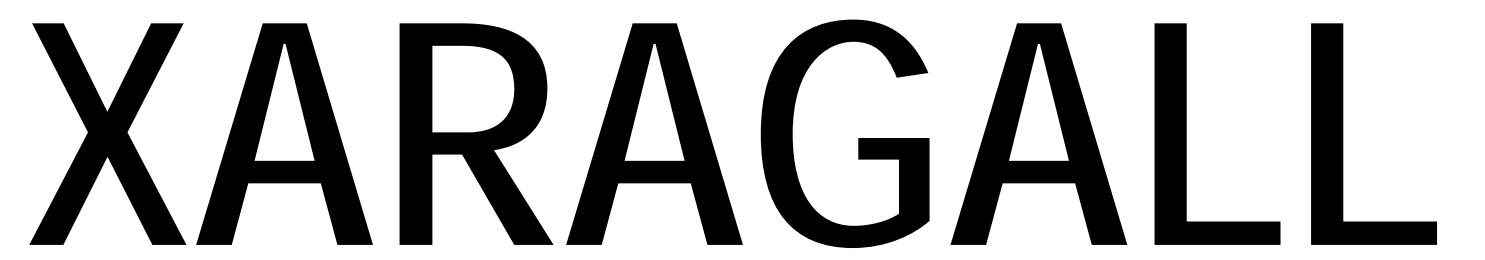

REVSTA DE CIÈNCIES DE LA CATALUNYA CENTRAL

\section{n. 12}

DESEMBRE 2014 


\title{
RECORREGUT DE RECERCA GEOLÒGICA I GEOAMBIENTAL PER LES COMARQUES DE L'ANOIA I DEL BAGES: DES DE LA SERRA DE RUBIÓ A CASTELLFOLLIT DEL BOIX I A RAJADELL
}

\author{
Josep Maria Mata-Perelló \\ Museu de geologia Valentí Masachs, Escola Politècnica Superior d'Enginyeria de Manresa \\ (EPSEM), Universitat Politècnica de Catalunya · BarcelonaTech (UPC), 08272 Manresa, Spain
}

\section{Joaquim Sanz Balagué}

Departament d'Enginyeria Minera i Recursos Naturals (EMRN), Escola Politècnica Superior d'Enginyeria de Manresa (EPSEM), Universitat Politècnica de Catalunya . BarcelonaTech (UPC), 08272 Manresa, Spain

Paraules clau: Depressió Geològica de l'Ebre, Materials terciaris, Materials quaternaris, Patrimoni miner

\section{Resum}

Itinerari realitzat el 26 de gener de 2014. En aquesta ocasió, es realitzarà un recorregut geològic que discorrerà en la seva totalitat per diferents indrets de la Depressió Geològica de I'Ebre; i més concretament pels sectors corresponents a la seva Depressió Central. D'aquesta manera, tot el recorregut transitarà entre afloraments dels materials terciaris (de l'Eocè i de I'Oligocè) i quaternaris que reblen aquesta depressió. Així, durant tot el recorregut, anirem trobant afloraments que corresponen als materials de la Formació Artés, que inicialment seran de característiques molt detrítiques. Més endavant ja veurem, exclusivament els afloraments de les margues i dels gresos de tonalitats rogenques.

Per altra banda, el recorregut transitarà inicialment per la comarca d'Anoia, pels sectors de la Serra de Rubió (dintre dels terme d'Òdena, fonamentalment; i ocasionalment pel de Rubió). Després, cap a ponent ja s'entrarà al Bages, transitant pels municipis de Castellfollit del Boix $\mathrm{i}$ Rajadell, exclusivament. 


\section{Objectius fonamentals}

Els objectius fonamentals que es pretenen aconseguir en aquest itinerari, es poden concretar en els següents aspectes generals:

1. Observació i descripció dels materials terciaris (exclusivament del Paleogen, i més concretament de l'Eocè i de I'Oligocè) de la Depressió Geològica de l'Ebre (i més exactament de la seva Depressió Central). Així, el recorregut de l'itinerari discorrerà íntegrament entre els afloraments del materials la Formació Artés, (del trànsit de I'Eocè a I'Oligocè), dintre d'aquesta formació, es veuran afloraments de calcolutites, gresos, guixos i conglomerats, segons els diferents indrets del recorregut de l'itinerari.

2. Observació de les estructures locals de la Depressió Geològica de l'Ebre, al llarg del recorregut de l'itinerari.

3. S'observaran, al llarg de tot el recorregut, els diferents elements relacionats amb el Patrimoni Geològic i Miner.

\section{Antecedents}

Pel que fa al recorregut del tram principal del present itinerari, no existeixen cap antecedent relatiu al recorregut, a excepció de dons antecedents parcials relatius a l'inici del mateix. Es tracta dels dos treballs nostres: Mata-Perelló (2014a i 2014b).

Pel que fa a la descripció de les mineralitzacions, seguirem fent esment d'alguns altres treballs nostres: Mata-Perelló (1990 i 1991); el primer relatiu a la comarca d'Anoia, el segon al conjunt de les mineralitzacions catalanes.

I, finalment, pel que fa a l'estructura geològica de la zona per la qual discorre l'itinerari, farem esment dels treballs de: Guimerà et altri (1982) i de RIBA et altri (1976). També farem esment d’un treball nostre: Mata-Perelló (1985).

Tots aquests treballs referenciats, i d'altres, figuren esmentats per ordre alfabètic a l'apartat dedicat a la BIBLIOGRAFIA.

\section{Recorregut de l'itinerari}

El recorregut de l'itinerari discorrerà inicialment per la comarca d'Anoia. I ho farà per l'entorn de la Serra de Rubió, pels termes d'Òdena i de Rubió 8en aquest cas molt puntualment). En aquest trajecte anoienc es faran dues aturades.

Després, el recorregut es dirigirà cap a llevant, seguint una pista en bon estat de conservació. En aquest trajecte s'entrarà a la comarca del Bages, fent-se dues noves aturades abans d'arribar a la carretera local BV - 1081. Finalment s'arribarà al poble de Castellfollit del Boix, per on es farà una nova aturada.

Després, el recorregut es dirigirà cap al Nord, per una carretereta, que després es convertirà en una pista en bon estat de conservació. Finalment s'arribarà al poble de Rajadell, per on finalitzarà aquest itinerari. En aquest darrer trajecte, es realitzaran diverses aturades. 


\section{Advertiments previs}

Com en altres recorreguts de RECERCA GEOLÒGICA I MINERALÒGICA... si es disposa del temps suficient, poden efectuar-se passant per totes les parades i filloles. En cas contrari, recomanem prescindir de les anomenades PARADES - CONDICIONALS.

També cal tenir en conte que part del recorregut, tant a l'inici de l'itinerari, com als seus darrers trams, es realitzarà per camins de terra, per la qual cosa caldrà prendre les degudes precaucions. En aquest recorregut, caldrà fer un llarg recorregut entre la carretera BV - 1031 i les immediacions de Castellfollit del Boix. I també una part del recorregut entre aquest darrer poble i el de Rajadell. Tot i així, en tots aquests trams el ferm és força bo i es pot circular be.

Cal tenir, com sempre, una cura molt especial de respecte a la natura, al llarg de tot el recorregut de l'itinerari, i també fora d'ell.

\section{Descripció de l'itinerari}

Com de costum, estructurarem el recorregut de I'itinerari en una sèrie de PARADES, que anirem veient. En cadascuna d'aquestes aturades farem un breu comentari (geològic 0 mineralògic, segons s'escaigui). En cada cas indicarem, entre parèntesi, el full topogràfic on es troba l'aturada.

En aquest cas, el recorregut de l'itinerari s'inclourà dintre dels següents fulls, del "Mapa Topográfico Nacional", realitzats a l'escala 1:50.000 per I'I.G.C. de España": 362 (o de Sant Joan de Vilatorrada, encara que abans es coneixia com a full de Calaf) i 391 (o d'Igualada).

Tanmateix, si s'escau, es pot utilitzar el Mapa Topogràfic Comarcal d'Anoia, editat per l'Institut Cartogràfic de Catalunya.

Així doncs, la relació de les aturades, que composen el recorregut d'aquest itinerari és la següent.

\subsection{Parada 1. IMMEDIACIONS DE LA CRUÏLLA DE LA CARRETERA DE RUBIÓ AMB LA BV - 1031, (terme municipal d’Òdena, comarca de I’Anoia). (Full 391)}

El recorregut I'iniciarem en aquest indret, situat a la cruilla de la carretera BV - 1031 (que enllaça Igualada amb els Prats de Rubió), amb la carretereta local que condueix cap el petit poble de Rubio, dintre de la Serra de Rubió.

Aquest indret es troba sobre un aflorament dels materials detrítics de la Formació Artés. Es tracta d'un nivell amb diversos paleocanals que configuren la part alta de la Serra de Rubió, constituint l'esgraó més alt del conjunt de relieves en cuesta.

Per d'altra banda, a aquest indret tenim un bon lloc d'observació de la part meridional de la comarca d'Anoia. Així, cap el centre es fa palesa la denominada Conca d'Òdena, per on afloren els materials eocènics que hem vist abans, pels voltants de la ciutat d'Igualada. Més cap el Sud, es fan presents els relleus de la Serralada Prelitoral (on afloren els materials paleozoics de I'Ordovicià i el mesozoics del Triàsic). I, també es pot veure des d'aquí com el riu Anoia travessa aquesta serralada, a través del Congost de Capellades. (fotografia 1). 


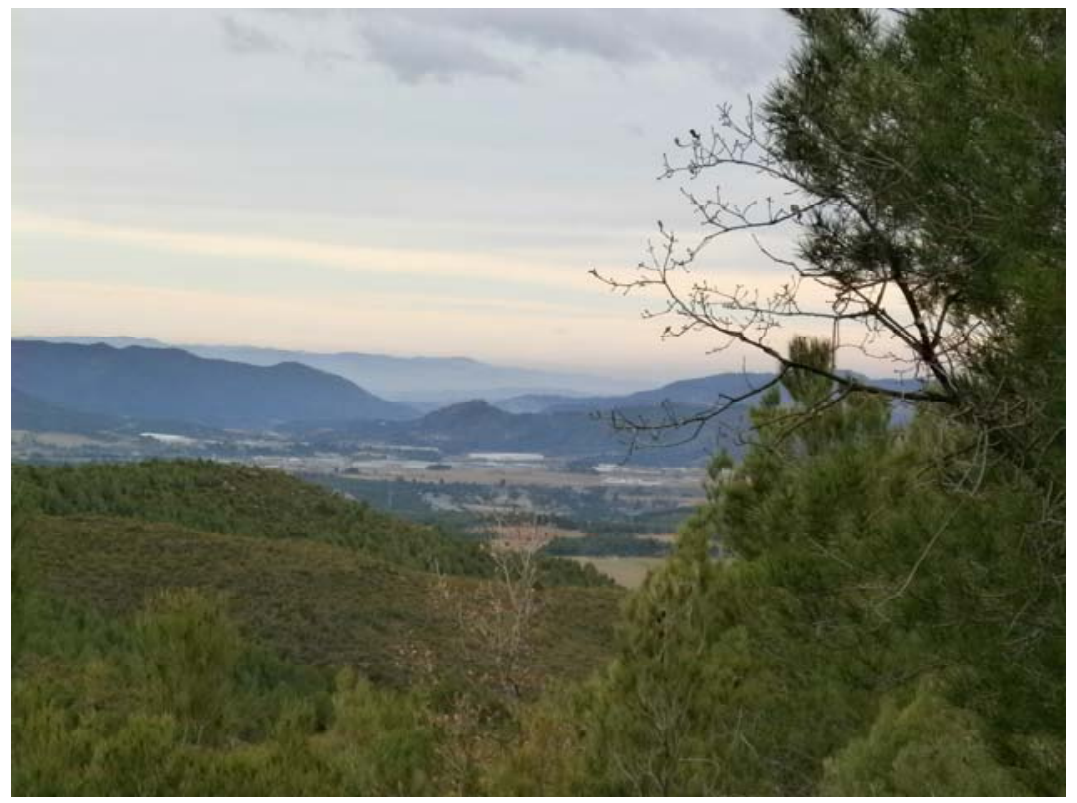

Fotografia 1. La Conca d'Òdena, des de les immediacions del Trencall de Rubió, Carretera BV - 1031

Cap el centre es veuen els materials eocènics que formen la Conca d'Òdena, pels voltants d'Igualada. Al centre es veu el relleu del Castell de la Pobla de Claramunt.

Més lluny es veu la vall del riu Anoia travessant la Serralada Prelitoral

I més lluny s'endevina la Depressió Prelitoral i la Serralada Litoral a I’Horitzó

Tanmateix, des d'aquest indret, mirant cap a llevant, es pot veure com aquests paleocanals configuren la part més alta de la Serra de Rubió, prop de la zona on hi ha els aerogeneradors. (fotografia 2).

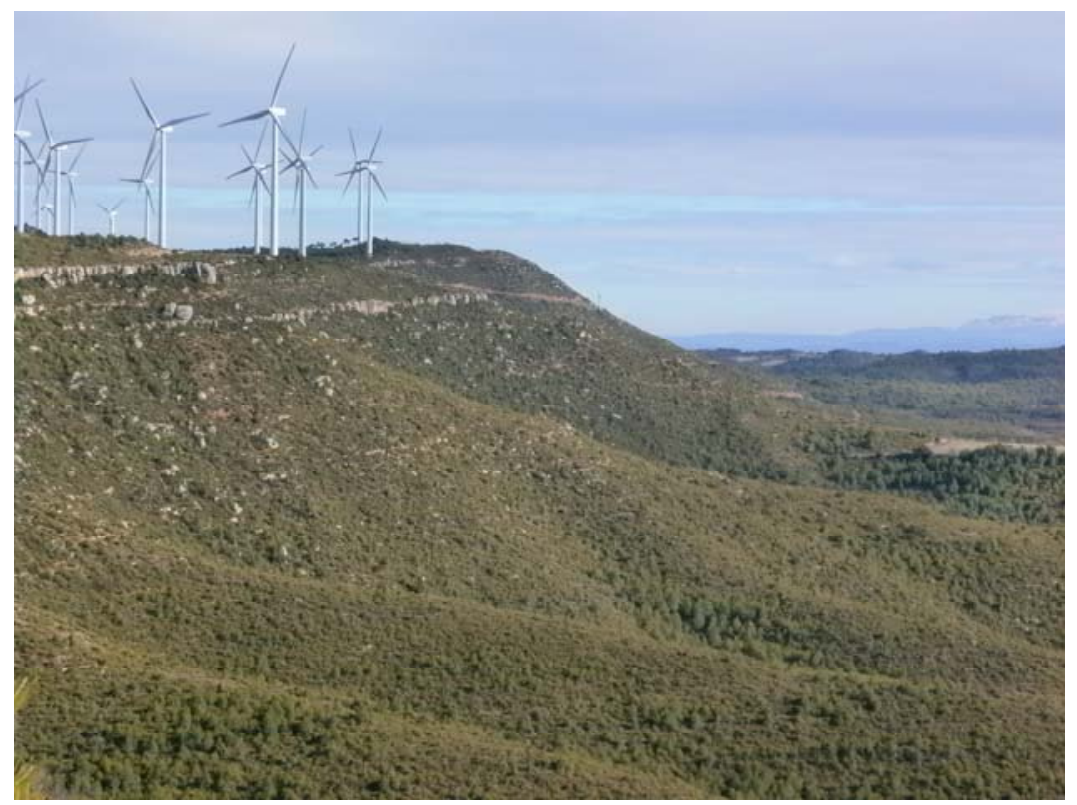

Fotografia 2. Aflorament del nivell de conglomerats a la part alta de la Serra de Rubió, sota dels aerogeneradors 


\subsection{Parada 2. MIRADOR DE LES ANTENES, CAMÍ CAP A CASTELLFOLLIT DE RIUBREGÓS, (terme municipal d'Òdena, comarca d'Anoia). (Full 391).}

Després de fer l'aturada anterior, ens caldrà fer un curt recorregut per la carretera local BV 1031 (anat cap al Nord, cap als Prat de Rei). Però ben aviat, es trobarà un trencall per la dreta, inicialment asfaltat que condueix cap a Castellfollit del Boix (entre altres indrets). Per aquest vial, en bon estat, cal anar cap a llevant. A poc més de $1 \mathrm{~km}$ de recorregut, per sota de les Antenes, caldrà fer una nova aturada, al costat d'uns cartells.

Des dels cartells anunciadors, es pot fer una bona visió tant de la Conca d'Òdena situada més avall, com del conjunt de relieves en cuesta, que son visibles per sota de la nostra posició. (fotografies 3 i 4).

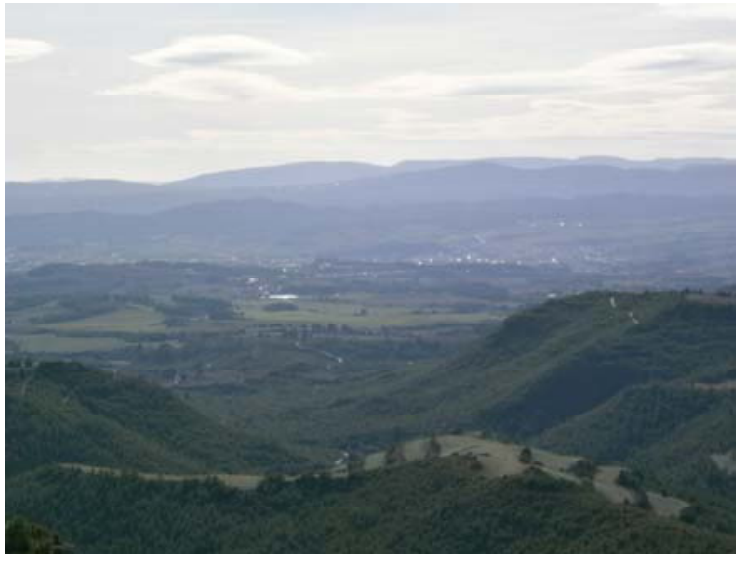

Fotografia 3. Un aspecte de la Conca d'Òdena, des de la Serra de Rubió

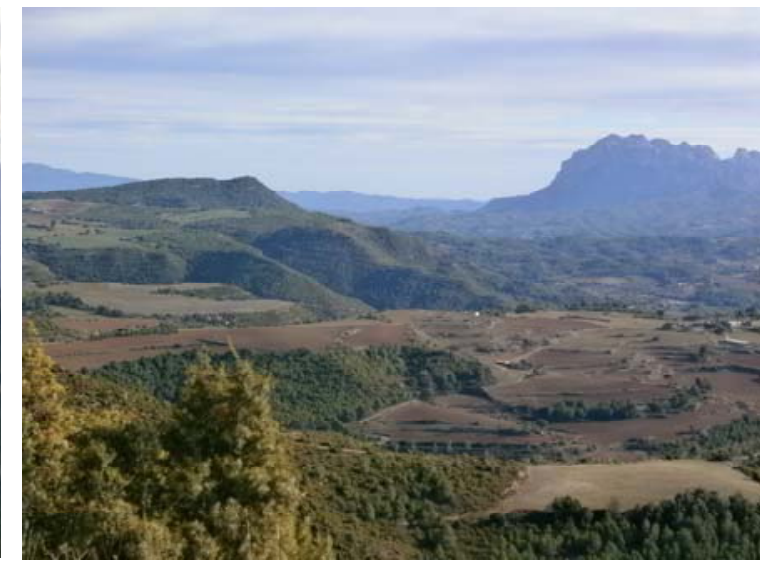

Fotografia 4. Conjunt de relieves en cuesta, visibles des la Serra de Rubió, amb Montserrat inclòs

Per d'altra banda, en aquest recorregut, hem trobat els materials esmentats anteriorment. Es tracta de nivells de la Formació Artés, en els que s'observen gresos i nivells de margues rogenques. Tanmateix es veuen nivells de conglomerats, que formen vistosos paleocanals, situats a la part alta de la Serra de Rubió, per on estem ara situats. (fotografia 5).

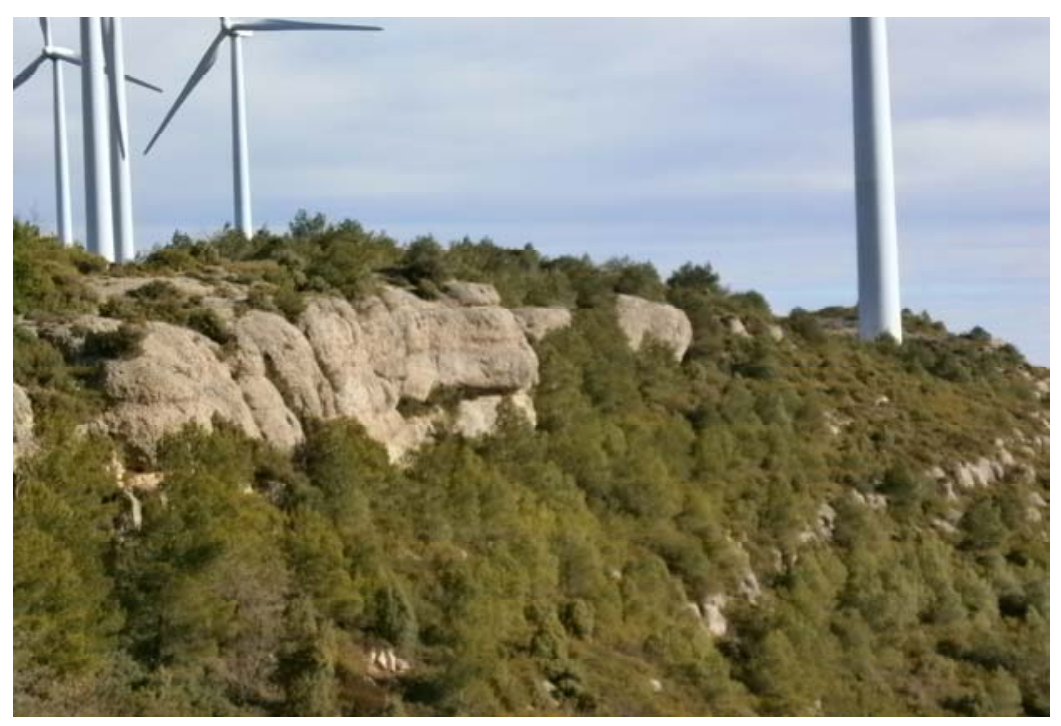

Fotografia 5. Un dels paleocanals situats a la part alta de la Serra de Rubió, per sota dels aerogeneradors 


\subsection{Parada 3. INICI DE LA PISTA CAP AL SECTOR NORD DELS AEROGENERADORS (TRENCALL DE CASTELLFOLLIT), (terme municipal de Rubió, comarca d'Anoia). (Full 391).}

Després de realitzar la parada anterior, cal continuar cap a llevant pel vial que es va dirigint cap a Castellfollit del Boix. A poc més de $1 \mathrm{Km}$ de l'indret anterior, trobarem una bifurcació, indicant el camí que es dirigeix cap a Castellfollit. Nosaltres continuarem breument per I'altre, tot fent una fillola. Al poc d'agafar-lo, tindrem ocasió de fer una nova parada, al sector septentrional de la cuesta on ens trobem situats. Així, haurem recorregut poc més de $1^{\prime} 5 \mathrm{Km}$.

En aquest recorregut, hem continuat trobant afloraments dels materials que hem vist anteriorment, en concret dels conglomerats que formen part dels paleocanals i que constitueixen la part alta de la Serra de Rubió.

En arribar a aquest indret, podem observar la part septentrional de la cuesta, cap on cabussen els estrats. Per d'altra banda, des d'aquesta posició hi ha un bon lloc per observar els relleus pirinencs. (fotografia 6).

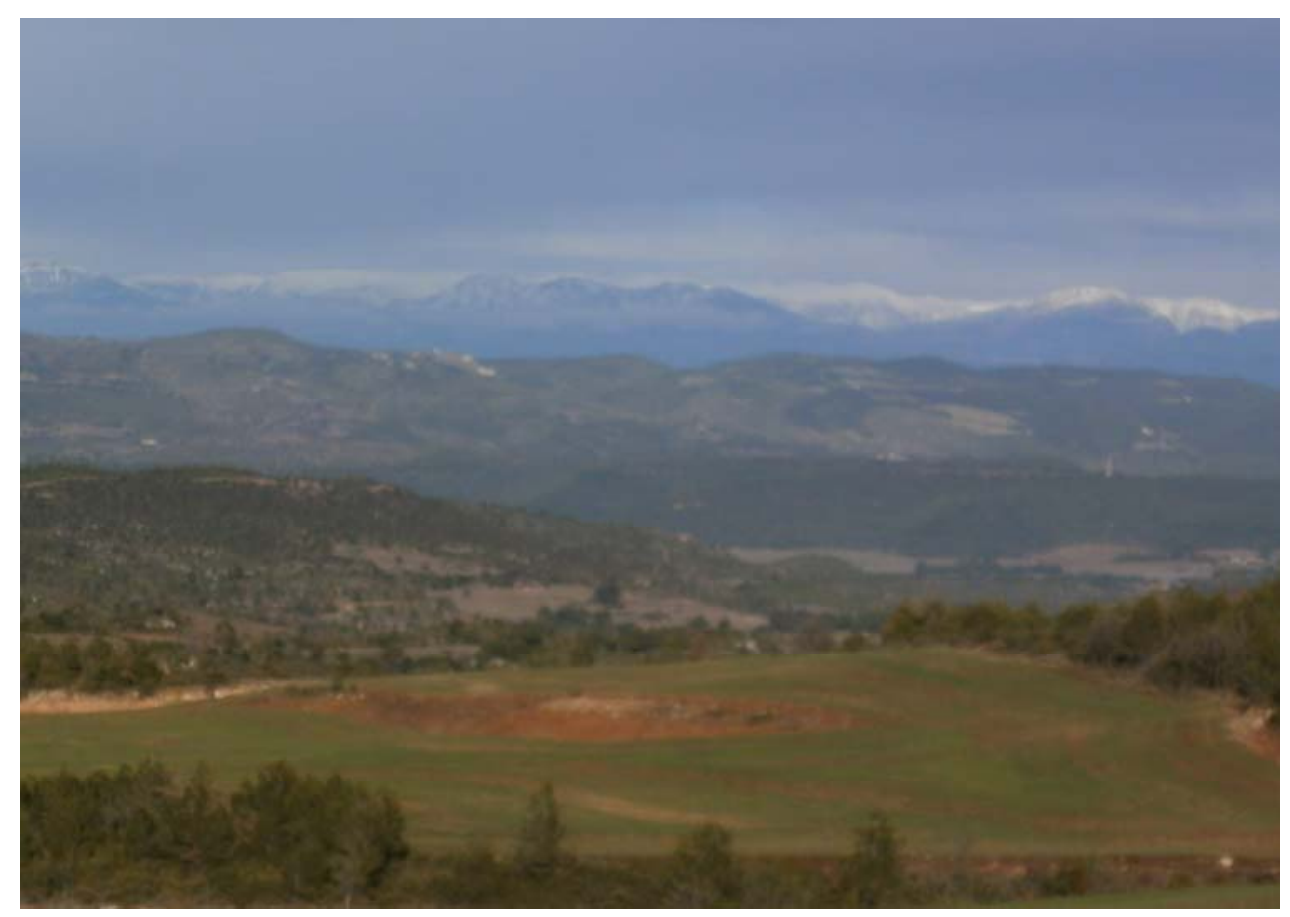

Fotografia 6. En primer terme, la part septentrional de la cuesta de la Serra de Rubió

Més lluny, la vall de la Riera de Rajadell al Bages. Més enllà, la serra de Castelltallat, sobre I’Anticlinal de Súria.

I al fons, els relleus pirinencs: la Serra del Verd, el Pedraforca,... 


\subsection{Parada 4. PROP DEL TRENCALL DEL CAMí CAP A ÒDENA, (Maians, terme de Castellfollit del Boix, comarca del Bages). (Full 391).}

Després de fer la parada anterior, cal retornar a la cruïlla, per tal de seguir cap a Castellfollit del Boix. Més endavant, en entrar al Bages, trobarem el trencall (per la dreta) que baixa cap a Òdena. Poc després, a uns $2 \mathrm{Km}$ de l'anterior, farem una nova aturada.

En aquest recorregut, hem anat trobant els materials esmentats a les aturades anteriors. Tot $\mathrm{i}$ això, hauran disminuiit els afloraments dels materials detrítics dels paleocanals. Així, haurem trobat força afloraments dels gresos i de les calcolutites rogenques de la Formació Artés.

Per d'altra banda, s'haurà fet força palès el Pla de Servitge, situat sobre la part septentrional de la cuesta mes baixa d'aquest sector. (fotografia 7). També haurem vist molt evidents els diferents relieves en cuesta, tant mirant cap a llevant (cap a Castellfollit del Boix) com mirant cap a ponent (cap a Rubió). (fotografia 8).

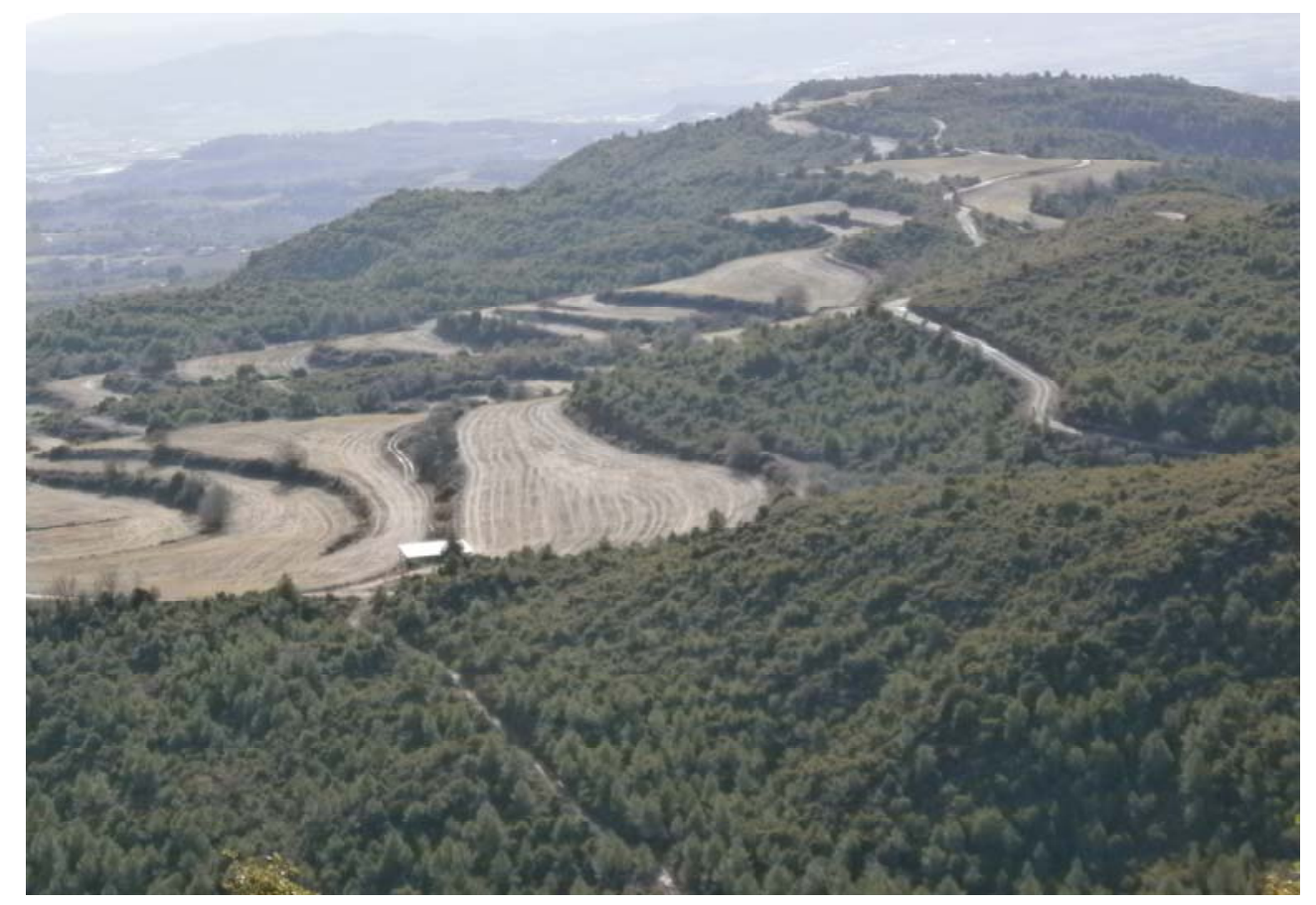

Fotografia 7. Pla de Servitge. Superfície septentrional de la primera cuesta 


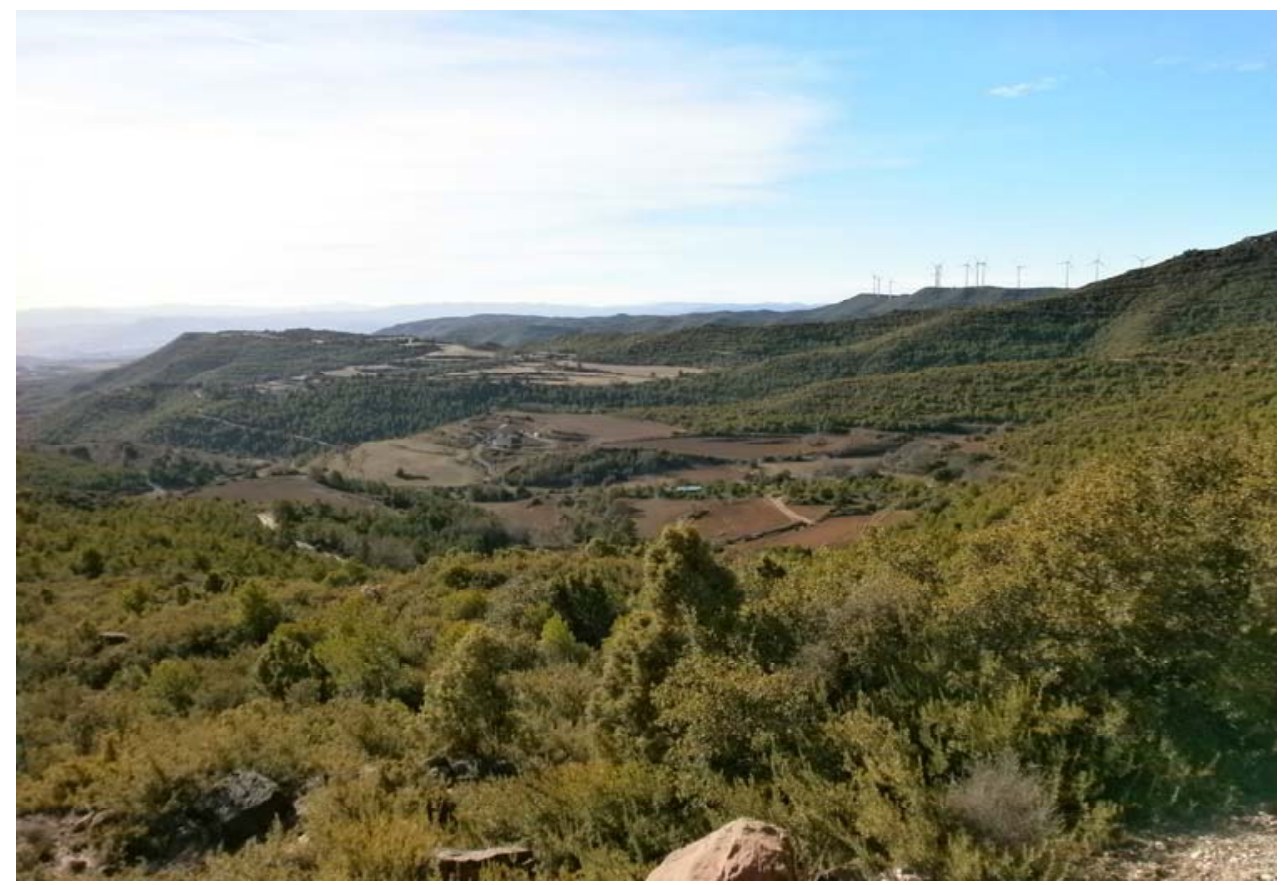

Fotografia 8. Conjunt de relieves en cuesta del peu de la Serra de Rubió. Es fa palès el Pla de Servitge

\subsection{Parada 5 - CONDICIONAL. IMMEDIACIONS DEL TRENCALL DEL CAMÍ AMB LA CARRETERA BV - 1031, (terme municipal de Castellfollit del Boix, comarca del Bages). (Full 391).}

Després de realitzar la parada anterior, cal continuar el recorregut cap a l'Est, amb la finalitat d'apropar-nos al proper poble de Castellfollit del Boix. Així, aviat arribarem a la cruïlla del camí que anem seguint amb la carretera BV - 1031, la qual comunica Maians amb Castellfollit. En arribar-hi, farem una nova aturada, a uns $2 \mathrm{Km}$ de l'anterior.

En aquest recorregut, hem anat trobant afloraments dels materials rogencs que hem vist anteriorment. Es tracta dels nivells de margues i de gresos que pertanyen a la Formació Artés. Aquests són també els materials que afloren on ara som.

Per d'altra banda, en arribar a aquest indret, haurem vist una plana, lleugerament inclinada cap el Nord. Aquesta plana es troba situada a cavall de la cinglera (cuesta) de Maians - Castellfollit del Boix. (fotografía 9). 


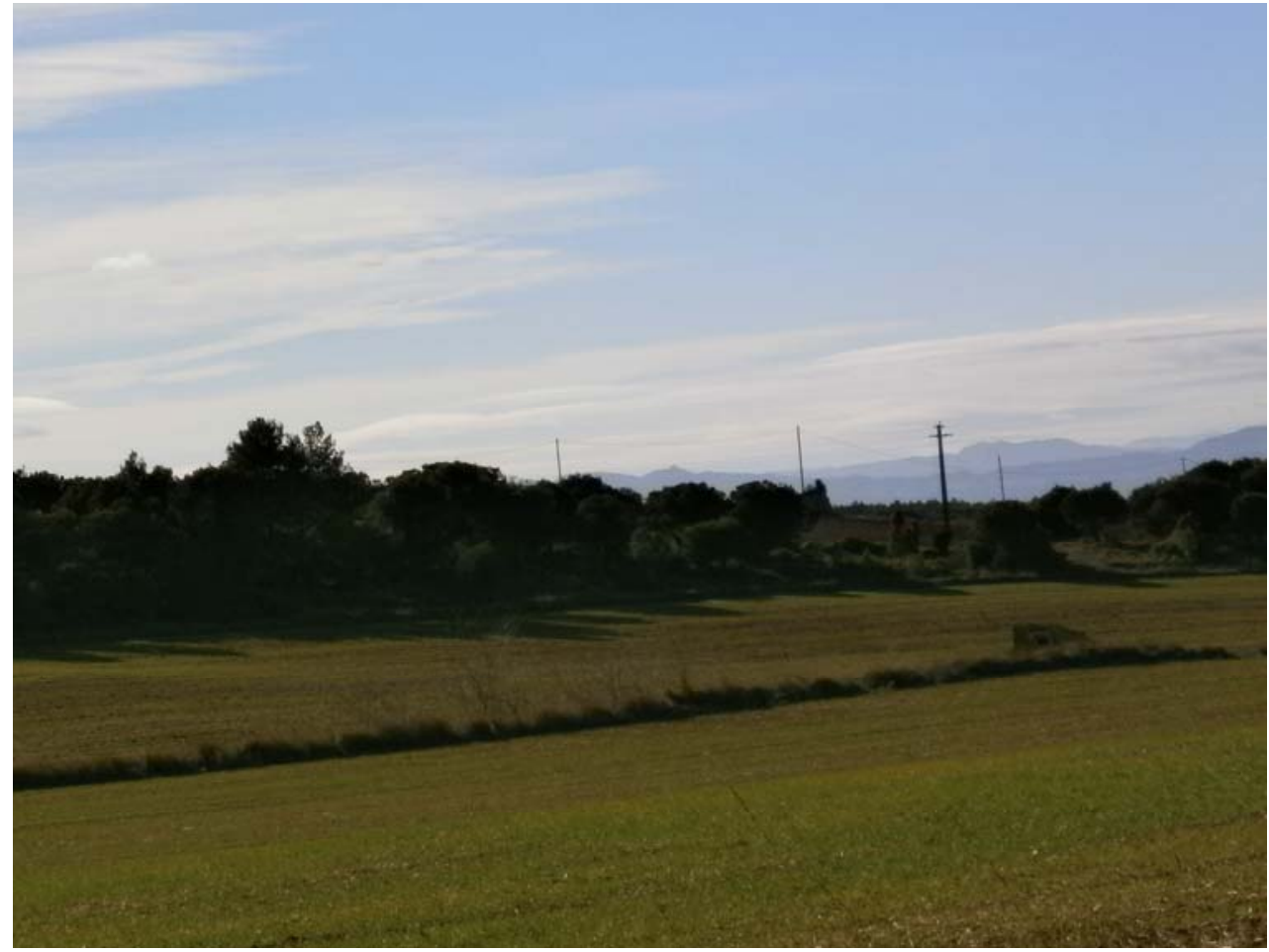

Fotografia 9. Pla de Castellfollit. Es troba a la part septentrional de la cinglera de Maians - Castellfollit; una de les cuestas d'aquest sector. Es pot veure pel color del sol, que hi afloren els materials de la Formació Artés

\subsection{Parada 6. IMMEDIACIONS DEL Km 1'5 DE LA CARRETERA BV - 1031, (terme municipal de Castellfollit del Boix, comarca del Bages). (Full 391).}

Després de fer l'aturada anterior, cal fer una fillola (en direcció cap a Maians) seguint la carretera local BV - 1031, anant cap el Sud. A $1 \mathrm{Km}$ de la cruilla i a quasi 1'8 Km de Castellfollit, podem fer una nova aturada.

Així, haurem trobat els materials esmentats a l'aturada anterior. Alhora, baixant cap a Maians, haurem trobat nivells de conglomerats. Aquests formen par de paleocanals i constitueixen la cinglera situada entre Maians i Castellfollit, a la que ens hem referit a l'aturada anterior. Tot i així, en un principi, haurem vist els nivells de les calcolutites i dels gresos de tonalitat vermelles.

Ara, a l'indret de la present aturada, podem gaudir d'una bona visió d'aquesta cinglera, sobre la que s'assenta el pla i la població de Castellfollit (al Nord d'on ara ens trobem situats). (fotografia 10). 


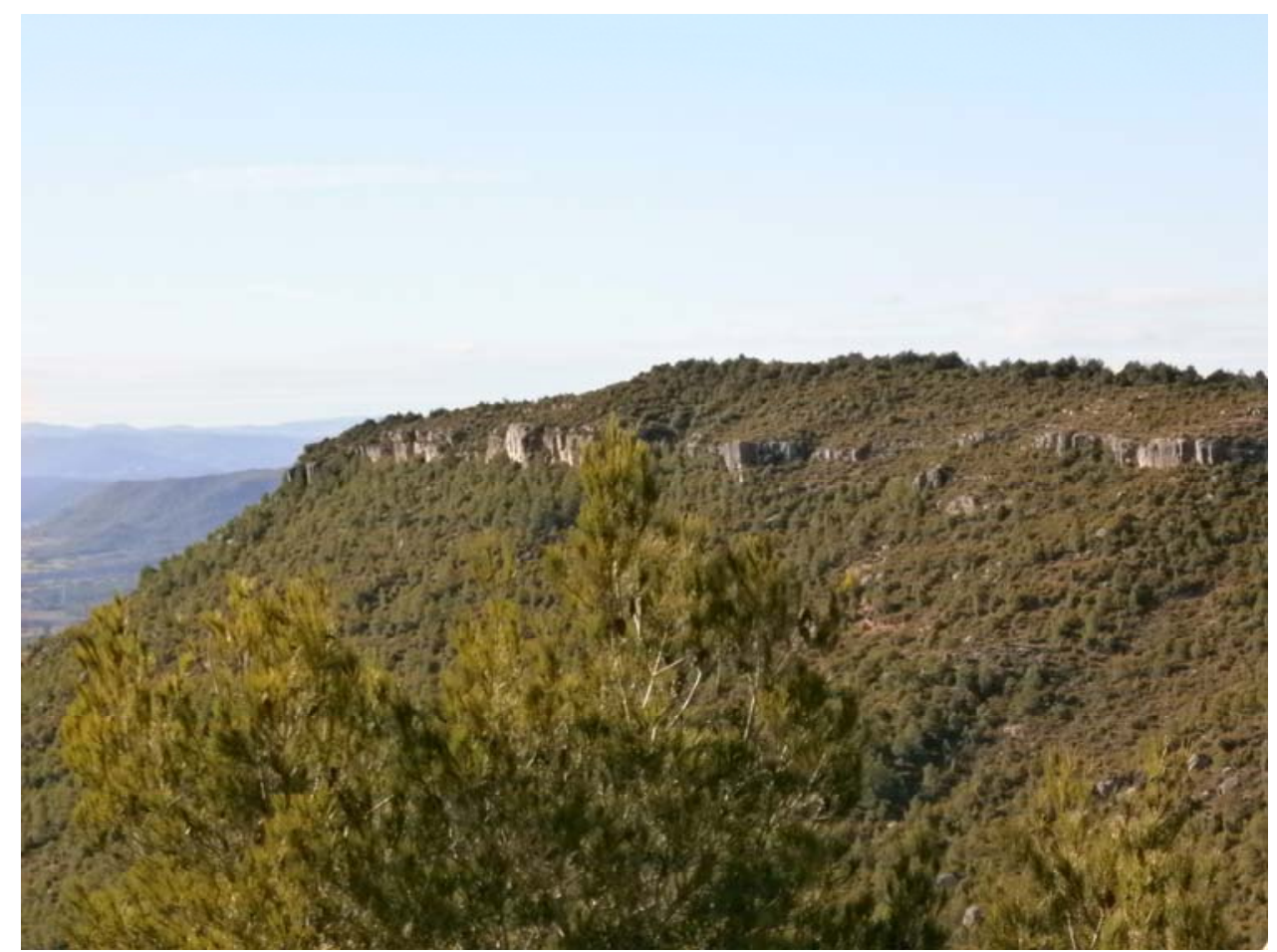

Fotografia 10. Cinglera de Maians - Castellfollit del Boix, des de la carretera que uneix els dos pobles. Es troba constituïda per nivells de conglomerats, tot formant paleocanals, dintre de la Formació Artés. Sobre aquesta cuesta es situa el Pla de Castellfollit, per on hi ha el poble esmentat, al Nord d'on ara som.

\subsection{Parada 7. PLA DE FONTANELLES, (Fontanelles, terme municipal de Castellfollit del Boix, comarca del Bages). (Full 391)}

Després de fer la parada anterior, cal anar cap al poble de Castellfollit del Boix, seguint per la carretera local BV - 1031, però en sentit contrari al que hem seguit abans. Així, arribarem aviat al poble (en menys de $2 \mathrm{Km}$ ). Després, des d'aquí, ens caldrà continuar per la carrereta asfaltada que es dirigeix cap al Pla de Fontanelles i cap a Rajadell. Nosaltres haurem de seguir per aquest vial, amb la intenció d'arribar a les immediacions del pla acabat d'esmentar. Així, en apropar-nos a menys de 0’5 Km, podem fer una nova aturada. D'aquesta manera, des de l'anterior, haurem recorregut prop de $7 \mathrm{Km}$, per tal d'arribar fins aquí.

En aquest recorregut, hem trobat afloraments dels materials esmentats anteriorment, concretament dels nivells de calcolutites (o margues) i de gresos de tonalitats rogenques, que pertanyen a la Formació Artés. Aquests materials deuen el seu color a la presencia d'un mineral de ferro, I'HEMATITES, el qual es troba en molt petita quantitat, però amb la suficient per donar el color roig als minerals incolors integrants de les roques que hem esmentat: la CALCITA, la CAOLINITA i el QUARS, fonamentalment. Aquest mineral és un òxid de Fe, amb valència 3, la qual cosa ens indica que ens trobem en un ambient oxidant, continental. Cal dir que seria el mateix, en cas de trobar-se present la LIMONITA, la qual donaria una coloració groc - bruna als estrats, a través del mineral GOETHITA,: però aquest no és el cas d'aquest indret.

Per altra banda, al llarg d'aquest recorregut, hem vist el relleu de Montserrat per diferents indrets, a través de les fondalades dels barrancs. (fotografia 11). 


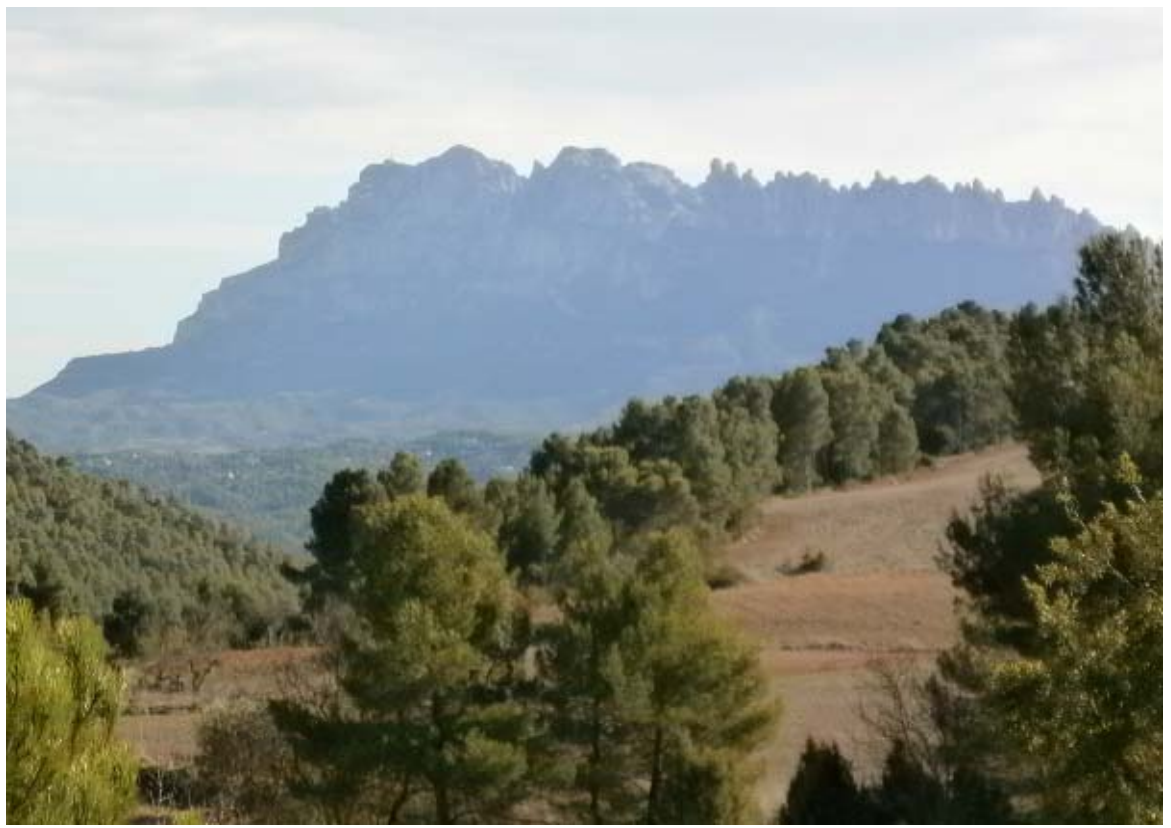

Fotografia 11. Els relleus de Montserrat, des de les immediacions del Pla de Fontanelles

Finalment, cal dir, que també s'han fet palesos els relieves en cuesta, a diferents indrets del recorregut, com a les immediacions del lloc de la present aturada, on es fa força palès el pla de Fontanelles, situat a l'esquena d'una d'aquestes cuestas, delimitada per un nivell de conglomerats. (fotografia 12).

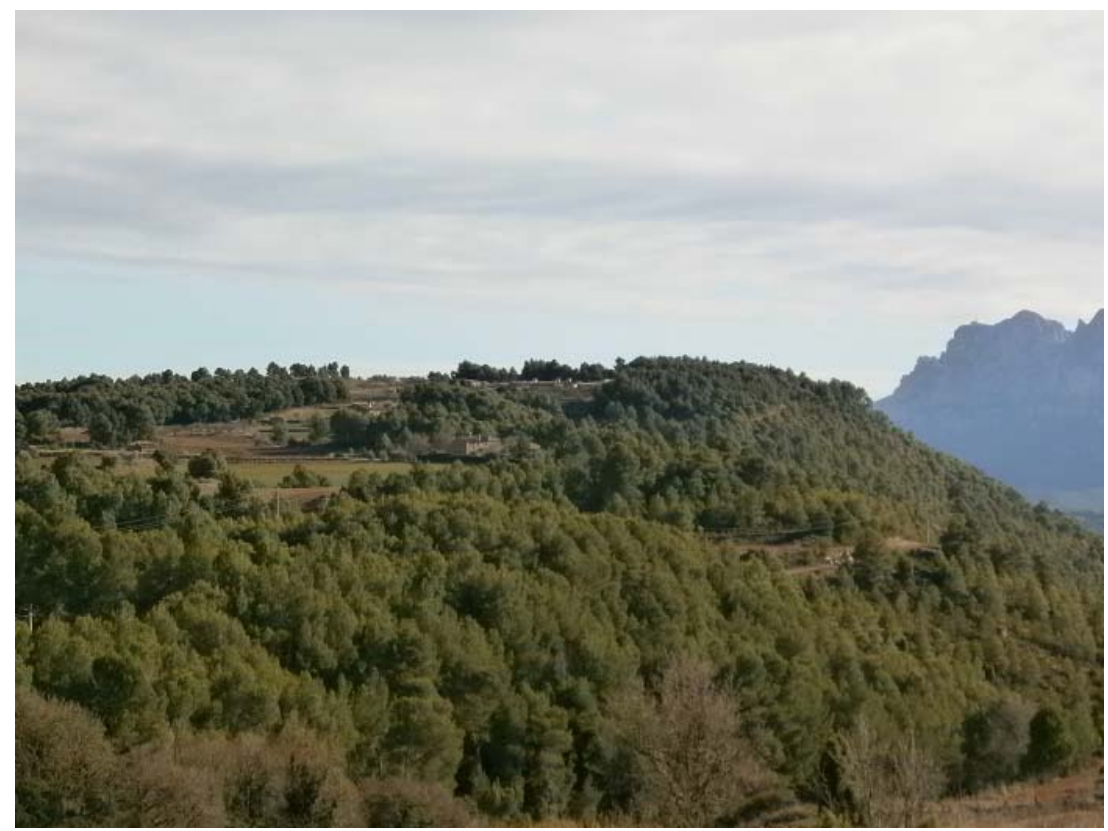

Fotografia 12. Un aspecte del Pla de Fontanelles, a l'esquena de la cuesta del mateix nom Al fons es poden veure els relleus de Montserrat 


\subsection{Parada 8. "CUESTA" DE CAN FONT FIGUERA, (terme municipal de Rajadell, comarca del Bages). (Full 362)}

Després re realitzar la parada anterior, caldrà continuar cap al Nord, anant ara cap el poble de Rajadell. Efectivament, en passar al seu terme, el camí deixarà d'estar asfaltat, encara que el seu estat serà força bo. Aviat, trobarem un trencall des d'on sortirà un brancal del camí que s'adreçarà cap a Manresa. Tot i així, nosaltres continuarem cap al Nord, cap a Rajadell. Aviat arribarem a les immediacions de Can Font Figuera. Però abans, es farà palesa una cuesta, al Nord del nostre recorregut. Per tal de veure-la, caldrà fer una nova aturada, a uns $2 \mathrm{Km}$ de la parada anterior.

En aquest recorregut, hem anat trobant afloraments dels materials esmentats a la parada anterior. Així, haurem trobat els nivells de les margues (calcolutites) i els dels gresos de tonalitats eminentment rogenges, clarament continentals. Aquests materials pertanyen a la Formació Artés, com hem vist al llarg de tot el recorregut del present itinerari, des del seu inici.

En aquest indret, es fa clarament palesa una cuesta, dintre del conjunt de relieves en cuesta, que hem anat trobant al llarg d'aquest itinerari. Aquesta es situa sobre un nivell de conglomerats, els quals es fan força palesos a diferents indrets del terme de de Rajadell. Es tracta de la que hem anomenat com a cuesta de la Font Figuera. (fotografia 13).

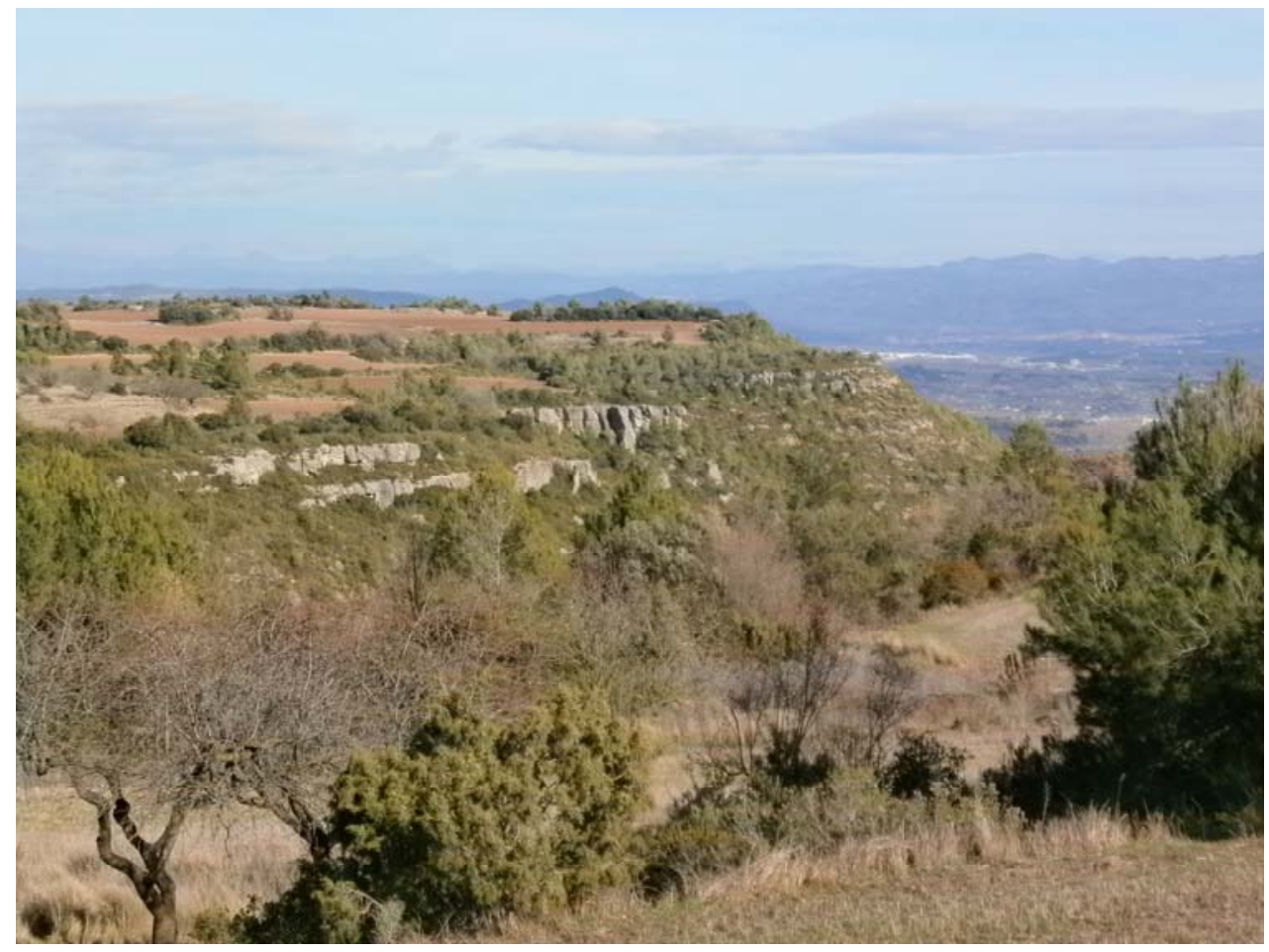

Fotografia 13. Un aspecte de la cuesta de la Font Figuera, amb el Pla de Can Maçana, dal. Prop de Rajadell

També cal dir que en aquest recorregut hem trobat diversos paleocanals, com els situats prop de Can Font Figuera. En observar-los, hem trobat a la base presencia de mineralitzacions de GLAUCONITA. 


\subsection{Parada 9. IMMEDIACIONS DE LA RIERA DE RAJADELL, (terme municipal de Rajadell, comarca del Bages). (Full 362)}

Després de fer la parada anterior, cal continuar cap al Nord pel camí que s'adreça poc a poc cap al poble de Rajadell. Aquest camí millora en arribar a Can Maçana, ja que es transforma en una carretereta asfaltada. Finalment, en arribar al proper poble de Rajadell, podem fer una nova aturada a la sortida del nucli principal, baixant cap a la Riera de Rajadell. Així, haurem recorregut uns $3 \mathrm{Km}$ més, aproximadament, per tal d'arribar fins on ara ens trobem situats.

En aquest recorregut, hem continuat trobant els materials esmentats anteriorment; és a dir els nivells de calcolutites (o margues) i els gresos de tonalitats vermelles, que pertanyen a la Formació Artés.

Tot i així, en part d'aquest recorregut, baixant cap a Rajadell, hem travessat els materials detrítics que hem vist de lluny a la parada anterior formant part de la cuesta de la Font Figuera. Així, ara, en trobar-nos a la part baixa de la població, podem veure com part d'aquests materials s'han anat desprenent, donant lloc a un interessant relleu ruïniforme a un caos montserratí. Tot això forma part del Patrimoni Geològic de la comarca del Bages, com veurem també a la propera aturada. (fotografia 14).

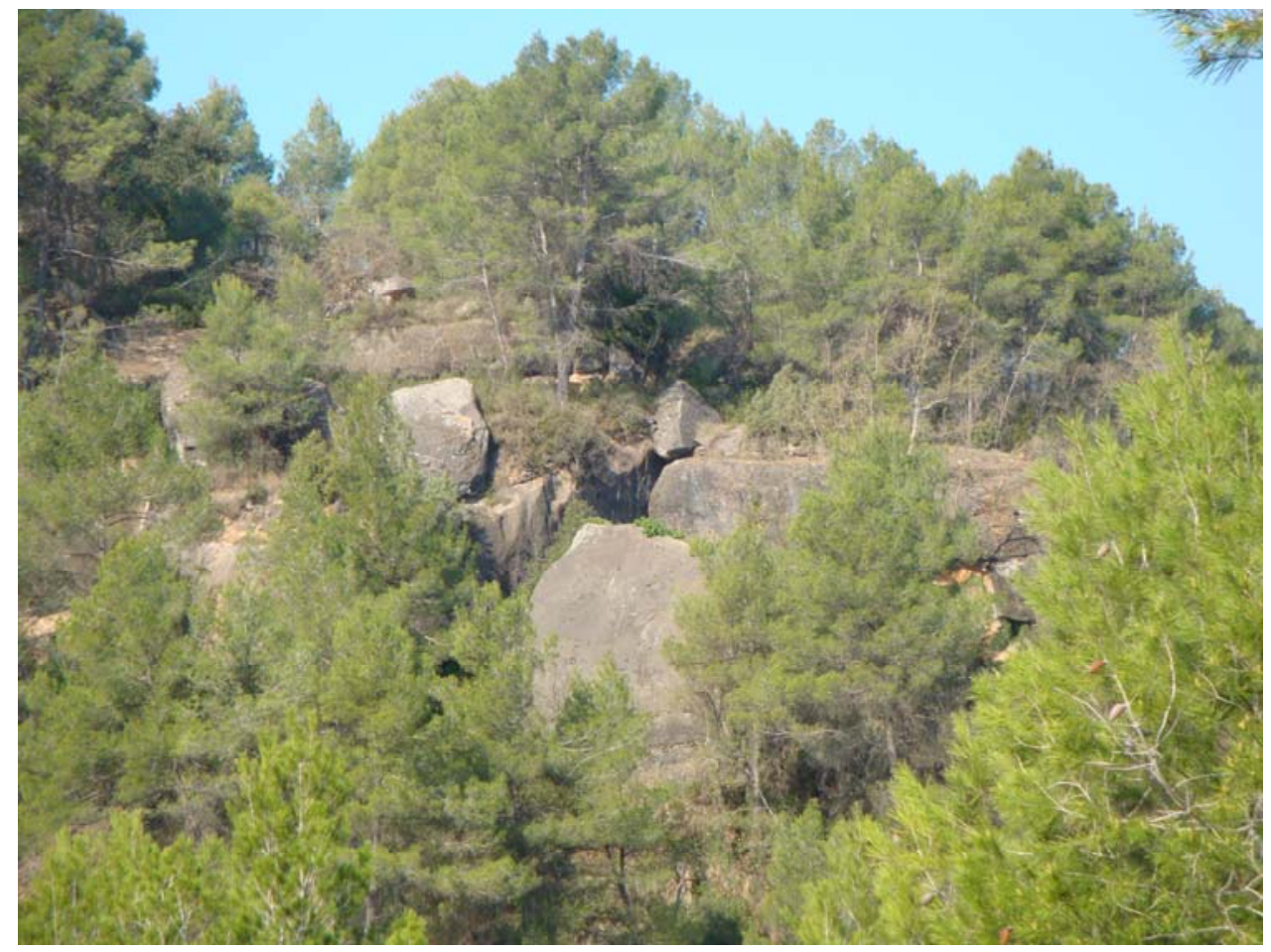

Fotografia 14. Relleu ruïniforme, dels voltants de Sallent. Nivells de conglomerats de la Formació Artés 


\subsection{Parada 10 - CONDICIONAL. TORRENT DE CAN BOSC, CAMÍ VELL A MANRESA, IMMEDIACIONS DE L'AUTOVIA C - 25, (terme municipal de Rajadell, comarca del Bages). (Full 362)}

Després de fer la parada anterior, cal arribar fins a la Riera de Rajadell. Tot seguit, cal agafar el camí vell de Manresa, per tal de fer la darrera aturada a uns $2 \mathrm{Km}$ del poble de Rajadell.

En aquest recorregut, haurem trobat els materials esmentats a les aturades anteriors, els quals pertanyen a la Formació Artés, com hem vist anteriorment. Aquests són també els materials que apareixen a l'indret de l'aturada.

En aquest lloc es fan evidents una sèrie d'esllavissades del nivell de conglomerats que hem vist a la parada anterior. Així, s'ha originat un interessant relleu ruïniforme. (fotografia 15).

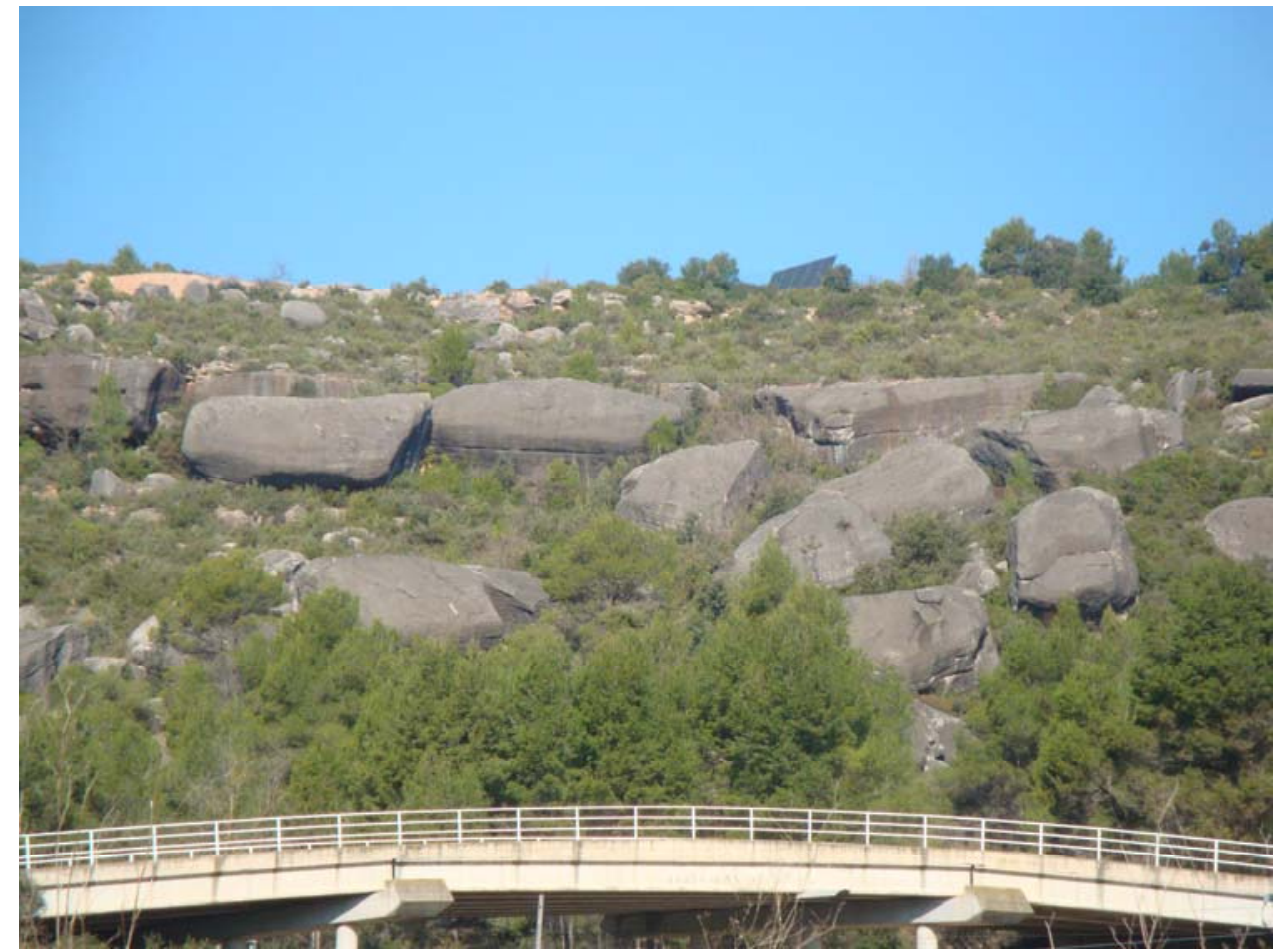

Fotografia 15. Relleus ruïniformes del torrent de Can Bosc, Rajadell, sobre I'Autovia C - 25

En aquest indret finalitza el recorregut de l'itinerari. 


\section{Bibliografia}

GUIMERÀ, J. et altri (1992).- Geologia (II), Història Natural dels Països Catalans, Vol.2, 547 pag. Enciclopèdia Catalana, S.A. Barcelona.

MATA - PERELLÓ, J.M. (1985).- Depressió de l'Ebre ?, Depressió Central ?. Revista Dovella, $\mathrm{n}^{\circ} 15, \mathrm{pp} .45-48$. Manresa.

MATA-PERELLÓ, J.M. (1990).- Inventari Mineralògic de la comarca d'Anoia. Revista Xaragall, $\mathrm{n}^{\circ} 24,40$ pag. Manresa.

MATA-PERELLÓ, J.M. (1991).- Els Minerals de Catalunya. Arxius de la Secció de Ciències, t. XCIII, 442 pag. Institut d'Estudis Catalans. Barcelona.

MATA-PERELLÓ, J. M. (2014a).- Recorregut de recerca geològica i geoambiental per la comarca d'Anoia: des d'Igualada a la Serra de Rubió, Sant Martí de Maçana, la Manresana i als Prats de Rei. Inèdit. 14 pàgines. Manresa.

MATA-PERELLÓ, J. M. (2014b).- Recorregut de recerca geològica i geoambiental per la comarca d'Anoia: des d'Igualada al Pla de Rubió, Rubió i a la Serra de Rubió. Inèdit. 12 pàgines. Manresa.

RIBA, O. et altri (1976).- Geografia Física dels Països Catalans, Edit. Ketres, 254 pàgines. Barcelona. 